\title{
$\mathrm{CCoAOMT}$ 유전자 발현 억제에 의한 현사시나무의 화학조성 변화*1
}

엄 인 용*2 - 김 광 호*2 - 이 수 민 $*^{3}$ - 이 용 섭*4 - 최 준 원*2,5†

\section{Characterization of Chemical Composition in Poplar wood (Populus deltoides) by Suppression of CCoAOMT Gene Expression*1}

\author{
In Yong Eom*2 Kwang Ho Kim*2 $^{* 2}$ Soo Min Lee*3 $\cdot$ Yong Sub Yi*4 \\ Joon Weon Choi ${ }^{* 2,5 \dagger}$
}

\section{요 약}

본 연구에서는 리그닌 전구물질 생합성에 관여하는 CCoAOMT (Caffeoyl-CoA-O-methyltransferase)유전자 의 발현을 분자생물학적으로 억제시킨 상태와 정상적인 상태에서 생장한 현사시나무를 대상으로 홀로셀룰로 오스, 리그닌과 단당류 조성에 관한 정량 분석을 각각 실시하였다. 그리고 각각의 목질바이오매스로부터 MWL (milled wood lignin)을 추출하여 메톡실기정량, $\mathrm{DFRC}, \mathrm{Py}-\mathrm{GC} / \mathrm{MS}, \mathrm{GPC},{ }^{13} \mathrm{C} \mathrm{NMR}$ 분석 등 리그닌의 화학 구조적 특성을 비교하였다. 정상재와 형질전환체의 홀로셀룰로오스 함량은 각각 $81.6 \%$ 와 $82.3 \%$ 로 큰 차이는 없었지만, 리그닌 함량은 각각 $21.7 \%$ 와 $18.3 \%$ 로 형질전환체가 약 $3.4 \%$ 정도 낮았다. 정상재와 형질전 환체의 구성 단당류 분석결과, 글루코오스는 각각 $511.0 \mathrm{mg} / \mathrm{g}$ 와 $584.8 \mathrm{mg} / \mathrm{g}$, 그리고 자일로오스는 각각 217.8 $\mathrm{mg} / \mathrm{g}$ 와 $187.5 \mathrm{mg} / \mathrm{g}$ 로 나타나 CCoAOMT 발현억제는 단당류 조성에 영향을 미치는 것으로 분석되었다. 각 시 료로부터 단리한 리그닌(MWL)의 메톡실기 정량에 따르면 CCoAOMT 발현을 억제한 시료에서 약 7\% 정도의 메톡실기가 감소하는 것으로 나타났고, 이는 ${ }^{13} \mathrm{C}-\mathrm{NMR}$ 분석과 $\mathrm{Py}-\mathrm{GC} / \mathrm{MS}$ 분석을 통하여 확인할 수 있었

*1 접수 2009년 12월 31일, 채택 2010년 3월 8일

*2 서울대학교 농업생명과학대학 산림과학부. Dept. Forest Science, CALS, Seoul National University, Seoul 151-921, Korea

*3 국립산림과학원 녹색자원이용부 바이오에너지연구과. Div. Forest Bioenergy, Dept. Forest Resources Utilization, Korea Forest Research Institute, Seoul 130-712, Korea

*4 호서대학교 한방화장품과학과. Dept. Herbal Cosmetic Science, College of Natural Science, Hoseo University, Chonan 330-713, Korea

*5 서울대학교 농업생명과학연구원. Research Institute for Agriculture and Life Science, Seoul National University, Seoul 151-921, Korea

† 교신저자(corresponding author): 최준원(e-mail: cjw@snu.ac.kr) 
다. 또한 $\mathrm{Py}-\mathrm{GC} / \mathrm{MS}$ 분석에 의하면 정상재와 형질전환체 리그닌의 $\mathrm{G} / \mathrm{S}$ 비율이 각각 0.59 와 0.44 로 나타난 점으로 미루어 $\mathrm{CCoAOMT}$ 발현 억제는 리그닌 생합성 과정에서 G unit 생합성보다 S unit 생합성에 더 많은 영향을 미치는 것으로 예측할 수 있다.

\section{ABSTRACT}

In this study, chemical compositions - holocellulose, lignin and monomeric sugars - were characterized with two poplar wood cell walls, one of which was grown at normal condition (CPW) and the other was genetically modified by antisence suppression of CCOAOMT gene expression (ACPW). Milled wood lignins were isolated from $\mathrm{CPW}$ and $\mathrm{ACPW}$ and subjected to methoxyl group, DFRC, Py-GC/MS, GPC, ${ }^{13} \mathrm{C}-\mathrm{NMR}$ analysis, respectively. There were few differences in holocellulose contents in both cell walls, which were determined to $81.6 \%$ in CPW and to $82.3 \%$ in ACPW. However, lignin contents in ACPW was clearly decreased by the suppression of CCOAOMT gene expression. In CPW $21.7 \%$ of lignin contents was determined, while lignin contents in ACPW was lowered to 18.3\%. The relative poor solubility of ACPW in alkali solution could be attributed to the reduction of lignin content. The glucose contents of CPW and ACPW were measured to $511.0 \mathrm{mg} / \mathrm{g}$ and $584.8 \mathrm{mg} / \mathrm{g}$ and xylose contents $217.8 \mathrm{mg} / \mathrm{g}$ and 187.5 $\mathrm{mg} / \mathrm{g}$, respectively, indicating that suppression of CCOAOMT gene expression could be also influenced to the formation of monomeric sugar compositions. In depth investigation for milled wood lignin (MWL) isolated from both samples revealed that the methoxyl contents at ACPW was decreased by $7 \%$ in comparison to that of CPW, which were indirectly evidenced by ${ }^{13} \mathrm{C}-\mathrm{NMR}$ spectra and Py-GC/MS. According to the data from Py-GC/MS S/G ratios of lignin in CPW and ACPW were determined to 0.59 and 0.44 , respectively. As conclusive remark, the biosynthesis of syringyl unit could be further influenced by antisense suppression of CCOAOMT during phenylpropanoid pathway in the plant cell wall rather than that of guaiacyl unit.

Keywords: poplar wood, CCoAOMT (caffeoyl-CoA-O-methyltransferase), milled wood lignin, DFRC, ${ }^{13} \mathrm{C}-\mathrm{NMR}$ spectra, Py-GC/MS

\section{1. 서 론}

화학적인 측면에서 목질바이오매스의 주요 용도로 는 펄프/종이 생산과 함께 최근 들어 이슈화되고 있 는 바이오에탄올 생산을 들 수 있다. 이들의 공통점 은 바이오매스 성분 중에서 $65 \sim 80 \%$ 를 차지하고 있 는 셀룰로오스/헤미셀룰로오스 성분만을 필요로 하 고, $25 \sim 35 \%$ 의 리그닌은 제거되어야 한다는 점이다. 특히 목질계 바이오에탄올 생산 공정에서 리그닌은 자체적으로 당화 및 발효를 저해할 뿐만 아니라 화학
적 - 물리적 처리에 의해서 생성된 다양한 화합물들 이 저해요인으로 작용될 수 있다. 또한 리그닌은 비 친수성의 페닐프로판 구조가 복잡하게 결합된 비결 정성의 고분자이다. 따라서 리그닌의 분해와 탈리그 닌화가 쉽지 않아서 펄핑 공정에서 리그닌을 제거하 는데 주로 머캅탄그룹과 같은 악취가 심하고 반응성 이 강한 약품을 사용하고 있다. 그 결과 바이오매스 로부터 바이오에탄올 생산을 위해 리그닌을 효과적 으로 제거할 목적으로 다양한 물리화학적 전처리 공 정이 시도되고 있다. 하지만 리그닌의 구조적 불명 
확성과 수종에 따른 다양한 화학 결합방식 때문에 침 엽수나 활엽수 등 리그닌 함량이 높은 목질바이오매 스에 적합한 전처리 방법은 아직 연구 중에 있다. 최 근 들어 산·염기 등 촉매에 의한 물리·화학적인 탈 리그닌화 전처리에 관한 연구와 함께 분자생물학적 으로 식물 세포벽에서 리그닌의 생합성 과정에 관여 하는 효소의 유전자 발현 조절을 통해 리그닌 함량을 줄이거나 리그닌 고분자의 화학결합 방식을 변화시 켜 리그닌을 보다 용이하게 제거하려는 연구가 진행 되고 있다(Guo et al., 2001; Pilate et al., 2002; Boudet et al., 2003). 이러한 리그닌 제거에 관련된 연구들은 목질바이오매스의 새로운 활용분야인 바 이오 에탄올 변환에 요구되는 비용을 줄일 수 있을 뿐만 아니라 화학약품의 사용량을 줄일 수 있는 환경 친화적 펄핑 공정개발에 기여할 것으로 기대되고, 나아가 생분해성 바이오소재로 리그닌의 용도개발 이 촉진될 것으로 기대된다.

리그닌은 페닐프로판 단량체가 결합된 방향족성 비결정성 고분자로서 바이오매스의 세포벽, 특히 이 차벽에 주로 분포해 있으며, 수목의 지지력을 부여 하고 도관요소를 통해 비투과성의 수분 이동 통로로 작용한다. 양치식물이상의 모든 유관속 식물의 세포 내에서 p-coumaryl (H-unit), coniferyl (G-unit)과 sinapyl alcohol (S-unit)이라는 3종의 리그닌 단량 체들이 모노리그놀 생합성 경로 (phenylpropanoid pathway)에 의해 생합성된다. 이러한 hydroxycinnamyl alcohol들은 peroxidase $/ \mathrm{H}_{2} \mathrm{O}_{2}$ 작용에 의해 라디칼 형태로 변환되고 이들은 서로 짝지음 반응 (coupling reaction) 메커니즘에 의해 여러 가지 특 징적인 단량체 간의 결합 $\left(\beta-0-4, \beta-5^{\prime}, 5-5^{\prime}, \beta-\beta^{\prime}\right.$, etc.)을 통해 리그닌이라는 거대한 페놀 고분자가 식 물 세포벽에 형성된다. Fig. 1에서 보듯이 $\mathrm{CCoAOMT}$ (caffeoyl-CoA-O-methyltransferase)는 모노리그놀 생합성 경로에서 caffeoyl CoA ester의 방향족 고리 의 3 번에 위치한 수산기를 메톡실기로 전이하거나, 5-hydroxyferuloyl CoA ester의 방향족 고리의 5번 에 위치한 수산기를 메톡실기로 전이시키는 반응에 관여하는 효소로서 식물 세포벽에 존재하는 리그닌 의 전구물질인 coniferyl alcohol과 sinapyl alcohol

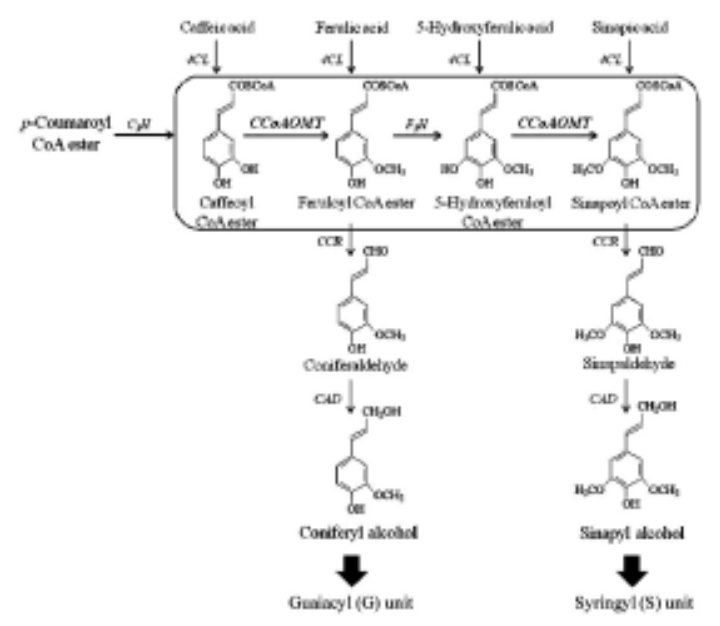

Fig. 1. The biosynthetic pathway for lignin precursors in plant cell wall (Anterola et al., 2002).

의 생합성에 관여한다.

따라서 식물 세포 내에 존재하는 $\mathrm{CCOAOMT}$ 유전 자의 발현을 분자생물학적으로 억제시키면 세포벽 내에 존재하는 리그닌의 G 및 S unit의 조성이 변화 될 것으로 예측된다. 반면, caffeoyl CoA ester 뿐만 아니라 5-hydroxyferulic acid derivatives들의 농도 는 증가될 것으로 예상되고 이러한 2 차 대사산물의 농도 변화는 생성되는 리그닌의 화학구조에 많은 영 향을 미칠 것이라고 예상된다.

본 실험은 모노리그놀 생합성 경로에서 $\mathrm{CCoAOMT}$ 유전자의 발현을 억제한 6 년생 현사시 목부와 정상 상태에서 생장한 6 년생 현사시 목부의 화학적 특성 을 비교하였으며, 각각 milled wood lignin (MWL)을 단리하여 $\mathrm{DFRC}, \mathrm{Py}-\mathrm{GC} / \mathrm{MS}$ 와 ${ }^{13} \mathrm{C}-\mathrm{NMR}$ 을 통해 구 조적인 차이를 분석하였다. 이러한 목질바이오매스 를 이용한 유전자 발현 조작 및 이에 따른 구조 변화 에 관한 연구는 향후 화석자원을 대체할 친환경 소재 로서 목질바이오매스를 용도에 맞게 맞춤형 바이오 자원으로 "design"화를 가능하게 할 것으로 기대된다. 


\section{2. 재료 및 방법}

\section{1. 공시재료}

본 실험에서 사용한 $\mathrm{CCoAOMT}$ 유전자는 현사시 나무(Populus deltoides)에서 분리하였으며, 분리한 유전자의 분자생물학적 특징은 Caffeoyl-CoA를 기 질로 확인하였다. 현사시나무(Populus deltoides)에 서 분리한 $\mathrm{CCoAOMT}$ 유전자를 $\mathrm{HPT}$ (Hygromycin phosphotransferase) 저항성 유전자가 삽입된 T-DNA 벡터(pBIB-HYG)에 Antisense 방향으로 클로닝하 여 형질전환을 실시하였다. 본 실험에서는 6 년생 현 사시나무 형질전환체 목부(Antisense CCoAOMT poplar wood ACPW)와 정상 상태에서 생장한 6년생 현사시나무 목부(Control poplar wood CPW)를 실 험용 분쇄기로 분쇄하여 40 mesh 이하의 목분을 제 조하였다. 각 시료의 화학조성은 에탄올과 벤젠을 혼합(v/v 1:2)한 유기용매로 추출성분을 제거한 후 에 분석하였다.

\section{2. 바이오매스 화학조성 분석}

홀로셀룰로오스 함량(\%)은 Wise 법(1946)으로 측 정하였고, 리그닌 함량(\%)은 $72 \%$ 황산가수분해법 (TAPPI method (T222 om-88))에 의거하여 정량하 였다. 주요 단당류 성분과 함량은 리그닌 정량 과정 에서 제조한 황산가수분해액을 60 배 희석한 후에 서 울대학교 농업과학공동기기센터의 Carbo Pac PA100 column $(4 \times 250 \mathrm{~nm})$ 과 ED50 pulsed amperometric detector가 장착된 고성능이온교환크로마토그래피 (HPAEC, Aionex system)로 정량하였다. 바이오매 스의 알칼리 용해도 $(\%)$ 는 $1 \mathrm{M}$ 의 수산화나트륨용액 에 약 $5 \mathrm{~g}$ 의 목분을 첨가하여 $37^{\circ} \mathrm{C}$ 에서 20 시간 동안 지속적으로 교반한 후 용액을 원심 분리하여 여과된 잔사를 동결건조한 후 알칼리 용해도 $(\%)$ 를 계산하 였다.

\section{3. 바이오매스의 리그닌 분석}

\subsection{1. 리그닌 결합방식과 분자량 측정}

현사시나무 정상재와 형질전환체에서 형성된 리그 닌(milled wood lignin)은 95\% aq. dioxane으로 단 리한 후에 분자량 분포, $\beta-0-4$ 결합빈도 및 메톡실 기를 정량하였다. 메톡실 그룹의 함량은 Viebock, Schwappach (1930)에 의해 고안된 분석방법을 변형 한 Sheri M. Baker (1996)법에 준거하여 측정하였 다. 단리한 MWL 내 $\beta-\mathrm{O}-4$ 결합 빈도는 $\mathrm{DFRC}$ 분석 법(derivatization followed by reductive cleavage; Ralph, 1997)에 의해 리그닌 단량체로 탈고분자화 시킨 후 Gas chromatography (HP 6890 series)로 정량하여 측정하였다. 자세한 분석 조건은 다음과 같다 - Column : DB-5 (0.25 mm I.D. ×60 m Agilent Technologies) Injection temp. : $220^{\circ} \mathrm{C}$ Oven temp. : $100 \sim 280^{\circ} \mathrm{C}, 5^{\circ} \mathrm{C} / \mathrm{min}$ Post run : 8 min Detector. MWL의 분자량은 피리딘과 무수초산(v/v 1:1)으로 MWL을 아세틸화시킨 후 THF (tetrahydrofuran) 용매에 녹여 겔크로마토그래피분석(GPCmax; Viscotek)을 통해 측정하였다.

\subsection{2. ${ }^{13} \mathrm{C}-\mathrm{NMR}$ 분석}

현사시나무 정상재와 형질전환체에서 형성된 리그 닌 구조 내 탄소의 결합양식의 차이를 살펴보기 위하 여 아세틸화된 현사시 MWL을 DMSO 용매에 녹여 서울대학교 농업과학공동기기센터의 High Resolution NMR Spectrometer (Bruker AVANCE 600, Germany)를 이용하여 분석하였다.

\subsection{3. 분석용 열분해 (Analytical $P y-G C / M S$ ) 산물 분석}

열에너지에 의한 바이오매스의 분해로 인하여 생 성되는 저분자 물질을 정성, 정량하여 현사시나무 정상재와 형질전환체의 구성성분과 열분해생성물을 비교해보기 위해 분석용 열분해를 실시하였다. 실험 을 수행한 분석용 열분해 장치에 관한 정보는 다음과 같다.

Ball-miller로 시료를 각각 실버컵(PY1-EC80F)에 
약 200 250 $\mu \mathrm{g}$ 을 주입한 후 internal standard인 Fluoranthene $10 \mu \ell$ (Fluoranthene $2.4 \mathrm{mg} / \mathrm{MeOH}$ $10 \mathrm{~m} \ell$ )를 첨가하였다. 그리고 실버컵 내에 잔류하고 있는 메탄올을 진공데시케이터에서 약 5 시간 동안 증발시킨 후 GC/FID (Agilent technologies 7890A) 에 장착된 열분해기(PY-2020iD)의 injector에 주입 하였다. 시료는 $475^{\circ} \mathrm{C}$ 인 조건(interface $320^{\circ} \mathrm{C}$ 인 조 건에서 약 10 초간 대기 후 열분해 시작)에서 약 10 초 동안 열분해되었으며 이때 생성된 가스는 헬륨기체 를 통해 GC 칼럼으로 운반(split ratio 100:1)된 후 FID와 MSD (Agilent Technologies 5975C)를 통한 열분해 생성물의 정량 및 정성 분석을 수행하였다. 분석에 이용된 칼럼과 오븐조건에 관한 정보는 다음 과 같다. 분석형 열분해기의 Ultra ALLOY-5MS/ HT $\left(0.25\right.$ mm I.D. $\times 30$ m Ultra ALLOY $\left.{ }^{\circledR}\right)$ 칼럼에서 분리된 열분해생성물은 $\mathrm{DB}-5 \mathrm{MS}$ (0.25 mm I.D. × $30 \mathrm{~m}$ Agilent Technologies)칼럼이 장착된 $\mathrm{GC}$ 로 이 송되어 각 성분별로 분리된 후에 $\mathrm{MSD}$ (Agilent Restrictor 1; $0.55 \mathrm{~m} \times 100 \mu \mathrm{m} ; 450^{\circ} \mathrm{C}$ )와 FID (Agilent Restrictor $2 ; 2.13 \mathrm{~m} \times 180 \mu \mathrm{m} ; 450^{\circ} \mathrm{C}$ )에 의한 각 성분에 대한 정성, 정량적 분석을 실시하였다. 분석 시간은 총 117.5 분이며, 오븐의 온도조건은 초기 $50^{\circ} \mathrm{C}$ (0.5분)에서 $2^{\circ} \mathrm{C} / \mathrm{min}$ 속도로 $280^{\circ} \mathrm{C}$ 까지 상승시 켰고, post run 조건은 $320^{\circ} \mathrm{C}, 3$ 분이었다.

\section{3. 결과 및 고찰}

\section{1. 바이오매스 화학조성}

Table 1은 현사시나무 정상재(control)와 형질전 환체(transgenic poplar)의 홀로셀룰로오스, 리그닌, 알칼리 용해도 함량의 결과이다. 형질전환체와 정상 재의 홀로셀룰로오스와 추출물 함량은 $1 \%$ 미만의 차이를 보이고 있지만 Klason method에 준거한 리 그닌 함량은 형질전환체가 정상재보다 약 $3.4 \%$ 낮게 측정되었다. 이는 현사시나무 형질전환체가 생장하 면서 CCoAOMT 유전자 발현의 억제에 의해 세포벽 내 목질화 과정(lignification)에서 리그닌 전구체인 $\mathrm{G}$ unit와 S unit의 생합성이 억제된 것으로 짐작할
Table 1. Chemical composition of Antisense CCoAOMT poplar wood (ACPW) and control poplar wood (CPW)

\begin{tabular}{cccccc}
\hline Sample & $\begin{array}{c}\text { Holocellulose } \\
(\%)\end{array}$ & $\begin{array}{c}\text { Lignin } \\
(\%)\end{array}$ & $\begin{array}{c}\text { Extractives } \\
(\%)\end{array}$ & $\begin{array}{c}\text { Alkali } \\
\text { solubility } \\
(\%)\end{array}$ \\
\hline \hline ACPW & $82.3 \pm 0.15$ & $18.3 \pm 0.02$ & $2.0 \pm 0.11$ & 24.8 \\
CPW & $81.6 \pm 0.48$ & $21.7 \pm 0.24$ & $1.4 \pm 0.02$ & 31.4 \\
\hline
\end{tabular}

수 있다.

여기서 방향족 고리의 $\mathrm{C}_{5}$ 에 위치한 하이드록실 그 룹 $(\mathrm{Mw}$ : ca. $17.0073 \mathrm{~g} / \mathrm{mol})$ 의 메틸화에 의해서 메 톡실 그룹 $(\mathrm{Mw}$ : ca. $31.0339 \mathrm{~g} / \mathrm{mol})$ 으로 $100 \%$ 전환 된다고 가정하면 1 몰 당 약 $14 \%$ 의 질량이 증가할 것 이므로 최대 $14 \%$ 이내의 범위에서 리그닌 함량차이 가 난다고 볼 수 있다. 따라서 추가적으로 $\mathrm{CCOAOMT}$ 유전자의 활성에 관한 연구가 진행되어야 리그닌 함 량 차이에 관한 고찰이 정량적으로 이루어질 것으로 판단된다. 한편, 수용성리그닌 함량은 형질전환체, 정상재 각각 $0.27 \%, 0.28 \%$ 로 산에 의해 리그닌으로 부터 가수분해된 저분자량 페놀성 물질의 조성은 큰 차이가 없을 것으로 사료된다. 그리고 일반적으로 바이오매스 내 리그닌이 알칼리에 쉽게 용해되는 점 을 감안하여 리그닌 함량이 높을수록 알칼리 용해도 가 높을 것이라는 판단하여 측정한 알칼리 용해도 결 과는 형질전환체가 정상재보다 약 $6.6 \%$ 낮았다. 이 결과는 $\mathrm{CCoAOMT}$ 발현 억제에 의해 목질화 과정에 서 리그닌의 화학구조적인 변화가 발생했다고 예상 되어 리그닌에 관한 추가적인 실험을 수행하였고 이 결과에 대해서는 다음 장에서 논하기로 한다.

Table 2에서 보듯이 총 단당류의 함량은 형질전환 체가 정상재에 비해 $4 \%$ 더 높았다. 형질전환체는 셀 룰로오스의 주요 성분인 글루코오스의 성분이 정상 재보다 약 $7 \%$ 정도 높은 반면에 헤미셀룰로오스의 주요 성분인 자일로스의 함량은 약 $3 \%$ 정도 낮았다. 홀로셀룰로오스 측정 결과와 단당류 분석결과를 비 교해 보면 홀로셀룰로오스 측정결과에 따른 형질전 환체와 정상재의 함량 차이는 약 $0.7 \%$ 이지만 단당류 분석 결과는 약 $4 \%$ 로 비교적 큰 차이를 보여주고 있 
엄인용·김광호 · 이수민 · 이용섭 · 최준원

Table 2. Determination of monomeric sugars in the cell wall of ACPW and CPW

\begin{tabular}{|c|c|c|c|c|c|}
\hline \multirow{2}{*}{ Sample } & Glucose & Xylose & Galactose & \multicolumn{2}{|c|}{ Total sugars } \\
\hline & & $(\mathrm{mg} / \mathrm{g})$ & & (mg/g) & (wt \%) \\
\hline ACPW & $584.8 \pm 59.0$ & $187.5 \pm 10.9$ & $14.7 \pm 1.6$ & $786.9 \pm 68.3$ & $78.7 \pm 6.8$ \\
\hline $\mathrm{CPW}$ & $511.0 \pm 39.9$ & $217.8 \pm 125$ & $18.2 \pm 1.1$ & $746.9 \pm 51.4$ & $74.7 \pm 5.1$ \\
\hline
\end{tabular}

다. 이 결과는 헤미셀룰로오스와 리그닌이 서로 결 합되어 있다는 점을 고려해보면 두 고분자간 상호작 용에 의해 바이오매스의 화학조성의 차이가 발생한 다고 예상해 볼 수 있다. 또한 목재를 구성하고 있는 헤미셀룰로오스와 리그닌 복합체의 결합양식과 바 이오매스 복합체 내 홀로셀룰로오스와 리그닌 분포 양식의 변화로 인한 산 가수분해 차이에 기인된다고 판단된다.

\section{2. 리그닌 추출 및 구조분석}

현사시나무 정상재와 형질전환체에서 생성된 리그 닌의 화학적 구조를 비교하기 위해 milled wood lignin (MWL)을 각각 단리 하였고 Table 3에 각 $\mathrm{MWL}$ 의 화학 분석 결과를 제시하였다. 형질전환체 -MWL에 존재하는 메톡실 그룹의 함량은 정상재 -MWL보다 약 $1.2 \%$ 정도 낮게 측정되었다. 메톡실 그룹의 함량 측정은 리그닌의 방향족성 고리에 위치 한 메톡실 그룹이 hydriodic acid (HI)와 $\mathrm{S}_{\mathrm{N}} 2$ 반응에 의해 생성된 methyl iodide $\left(\mathrm{CH}_{3} \mathrm{I}\right)$ 의 정량을 통해 이 루어진다.

따라서 위 측정결과는 모노리그놀 형성과정에서 $\mathrm{C}_{5}$ 에 부착된 수산기의 메틸화에 관여하는 $\mathrm{CCoAOMT}$ 의 발현이 억제되었기 때문에 형질전환체-MWL에서 메톡실기 함량이 정상재보다 낮게 측정되었으리라 판단된다. 정상재-MWL의 메톡실 그룹의 함량을 $100 \%$ 로 간주하면, 형질전환체-MWL의 메톡실 그룹 의 함량은 $93.3 \%$ 로 측정되어 $\mathrm{CCoAOMT}$ 발현 억제 에 의해 약 $6.7 \%$ 의 G uint 및 S unit 이 감소된 것으 로 판단된다(Table 3).

DFRC 분석에 의한 guaiacyl과 syringyl unit의 함 량을 살펴보면 정상재에 단리한 리그닌이 약 14 $\mu \mathrm{mol} / \mathrm{g}, 34 \mu \mathrm{mol} / \mathrm{g}$ 으로 형질전환체의 guaiacyl unit
과 syringyl unit보다 더 높았다. 여기서 리그닌의 주 요 결합양식인 $\beta-0-4$ 결합을 선택적으로 분해하는 $\mathrm{DFRC}$ 분석의 특징과 리그닌 내 syringyl unit은 주 로 $\beta-0-4, \beta-\beta^{\prime}, \beta-5$ 결합을 이루고 있다는 점을 고려해 볼 때 형질전환체-MWL 내 syringyl unit의 감소에 의해서 $\beta-0-4$ 결합의 감소를 초래하여 정상 재-MWL에 비해 리그닌의 함량이 더 낮게 측정된 것 이라고 추측해 볼 수 있다. 한편, $\mathrm{DFRC}$ 법에 의해서 형질전환체-MWL과 정상재-MWL에서 $\mathrm{G} / \mathrm{S}$ 비율이 동일하게 측정된 결과에 대해서는 활엽수 내 리그닌 단량체들의 결합양식 중 $\beta-1, \beta-\beta^{\prime}$ 의 빈도가 침엽 수보다 높다는 점(Erickson et al., 1973)을 감안한 다면 $\mathrm{CCOAOMT}$ 발현 억제에 의해 리그닌 단량체의 결합양식의 변화에 대한 가능성을 배제할 수 없다. 따라서 모노리그놀 생합성 경로에서 생성된 $\mathrm{syri}^{-}$ ngyl unit가 짝지음 반응에 의한 리그닌 고분자화에 참여하게 되는 시점과 방식, 또는 $\mathrm{CCoAOMT}$ 유전자 와 상호작용을 하는 다른 효소(e.g., $\mathrm{CAD})$ 의 활성 여부에 관한 부가적인 연구가 필요하다고 판단된다 (Lewis et al., 2002). GPC 분석에 의한 형질전환체 -MWL와 정상재-MWL의 평균 분자량은 각각 10,893 과 9,781 로 측정되었고 리그닌의 생합성 경로에서 syringyl unit이 생성되는 과정이 차단되었기 때문에 메톡실 그룹의 함량이 낮아져 분자량은 형질전환체 -MWL에서 약 $10 \%$ 정도 낮은 결과가 나온 것으로 예측된다. 다분산도 값은 형질전환체-MWL (2.11)이 정상재-MWL (2.47)보다 낮기 때문에 중합도는 더 높을 것으로 예측된다. 
Table 3. Determination of methoxyl groups and $\beta-0-4$ linkages in the milled wood lignin isolated from CPW and ACPW

\begin{tabular}{cccccc}
\hline \multirow{2}{*}{ Sample } & \multirow{2}{*}{$\begin{array}{c}\text { Methoxyl group } \\
\text { in MWL }(\%)\end{array}$} & \multicolumn{4}{c}{ DFRC analysis $(\mu \mathrm{mol} / \mathrm{g}$ sample) } \\
\cline { 3 - 6 } & & G unit & S unit & G + S unit & G/S \\
\hline \hline ACPW-MWL & $16.1 \pm 0.65$ & $298.0 \pm 3.56$ & $761.0 \pm 8.85$ & $1059.0 \pm 12.41$ & 0.4 \\
CPW-MWL & $17.3 \pm 0.12$ & $312.2 \pm 2.24$ & $795.2 \pm 5.86$ & $1107.4 \pm 8.10$ & 0.4 \\
\hline
\end{tabular}

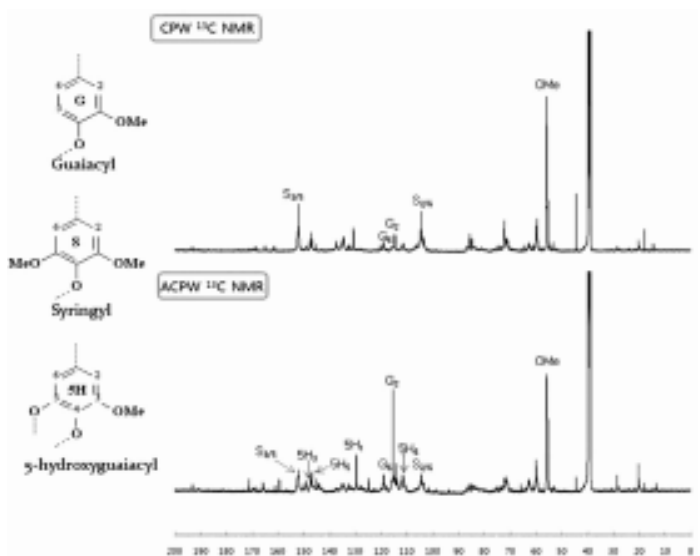

Fig. 2. ${ }^{13} \mathrm{C}-\mathrm{NMR}$ spectra of milled wood lignins isolated from control poplar wood (CPW) and Antisense CCOAOMT poplar wood (ACPW).

Fig. 2는 형질전환체-MWL과 정상재-MWL의 ${ }^{13} \mathrm{C}^{-}$ $\mathrm{NMR}$ 스펙트럼의 결과이다. 스펙트럼의 각 탄소에 해당되는 peak를 정량하지 않았지만 $\mathrm{CCoAOMT}$ 형 질 억제의 결과로 syringyl unit은 감소되는 반면 5-hydroxyguaiacyl의 유도체가 증가되었다는 것을 두 스펙트럼의 비교를 통해 확인할 수 있다. 형질전 환체의 ${ }^{13} \mathrm{C}-\mathrm{NMR}$ 스펙트럼을 살펴보면 syringyl unit 은 2/6번 탄소(signal in $105 \mathrm{ppm}$ )와 3/5번 탄소 (signal in $154 \mathrm{ppm}$ ) peak의 면적은 정상재의 ${ }^{13} \mathrm{C}-$ $\mathrm{NMR}$ 스펙트럼에 비해 크게 감소되었음을 알 수 있 었으며, 정상재에서 잘 나타나지 않던 $5 \mathrm{H} \quad$ (5hydroxyguaiacyl)의 peak가 형질전환체의 스펙트럼 에 잘 나타나 있는 것을 확인할 수 있다(Marita et al., 2003; Ralph et al., 2001).

Fig. 3과 Table 4는 현사시나무 정상재와 형질전환
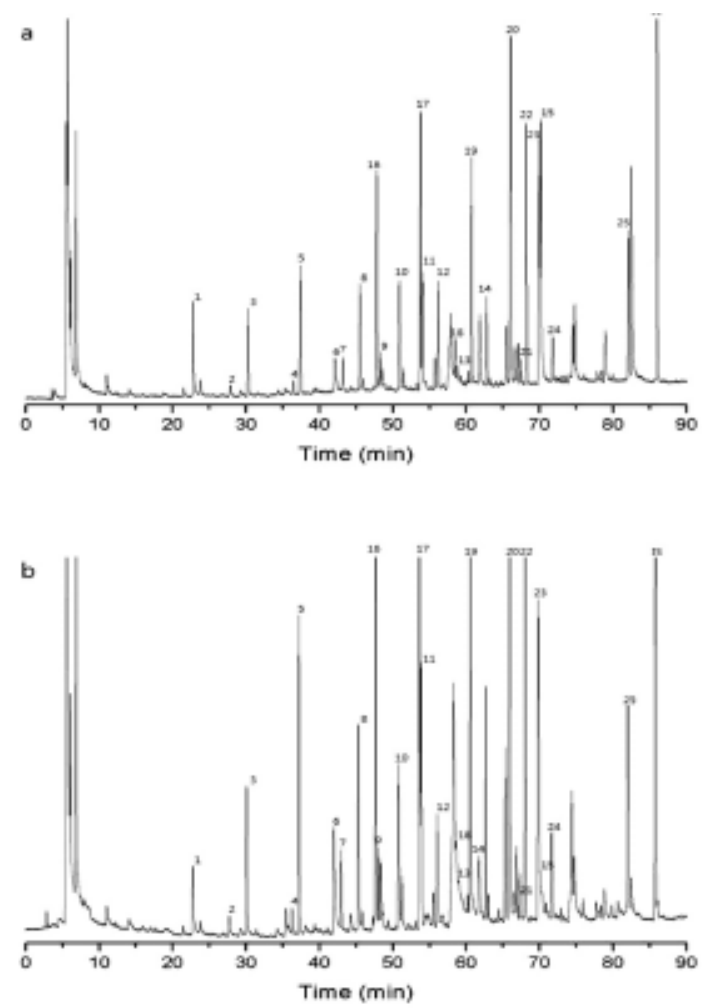

Fig. 3. Pyrograms of milled wood lignins isolated from control poplar wood (CPW; a) and Antisense CCOAOMT poplar wood (ACPW; b).

체의 분석용 열분해(Analytical Py-GC/MS)에 의한 크로마토그램과 열분해 산물에 대한 분석결과를 각 각 나타내었다. 정상재와 형질전환체 모두 총 25 종 의 페놀성 단량체가 검출되었으며 Internal standard를 이용하여 각 peak의 면적을 정량하였다. 그 리고 $\mathrm{H}, \mathrm{G}, \mathrm{S}$ type으로 페놀성 모노머를 분류하였고 
Table 4. Monomeric phenolics released from analytical pyrolysis of poplar milled wood lignin

\begin{tabular}{|c|c|c|c|c|c|}
\hline \multirow{2}{*}{ No. } & \multirow{2}{*}{ RT } & \multirow{2}{*}{ Pyrolytic products } & & \multicolumn{2}{|c|}{ Poplar MWL (\%) } \\
\hline & & & & $\mathrm{CPW}$ & ACPW \\
\hline 1 & 22.79 & Phenol & \multirow{2}{*}{ H-types } & 1.00 & 0.34 \\
\hline \multirow[t]{2}{*}{2} & 27.84 & 2-Methylphenol (O-Cresol) & & 0.12 & 0.09 \\
\hline & & Sum & & 1.12 & 0.43 \\
\hline 3 & 30.26 & 2-Methoxyphenol (Guaiacol) & \multirow{13}{*}{ G-types } & 0.78 & 0.51 \\
\hline 4 & 36.48 & 2-Methoxy-5-methylphenol (Isocreosol) & & 0.18 & 0.12 \\
\hline 5 & 37.43 & 2-Methoxy-4-methylphenol (Homocreosol) & & 1.61 & 1.51 \\
\hline 6 & 42.10 & 3-Methoxy-1,2-benzenediol (3-Methoxycatechol) & & 0.45 & 0.74 \\
\hline 7 & 43.18 & 4-Ethyl-2-methoxyphenol (Ethyl guaiacol) & & 0.28 & 0.28 \\
\hline 8 & 45.50 & 2-Methoxy-4-vinylphenol (Vinyl guaiacol) & & 0.90 & 0.70 \\
\hline 9 & 48.26 & 2-Methoxy-4-(2-propenyl)-phenol (Eugenol) & & 0.27 & 0.26 \\
\hline 10 & 50.89 & 2-Hydroxy-3-methoxy-benzaldehyde (Vanillin) & & 1.65 & 1.02 \\
\hline 11 & 54.03 & 2-Methoxy-4-(1-propenyl)phenol (Isoeugenol) & & 1.06 & 0.81 \\
\hline 12 & 56.17 & 1-(4-Hydroxy-3-methoxyphenyl)ethanon (Acetoguaiacone) & & 0.97 & 0.45 \\
\hline 13 & 58.73 & 1-(4-Hydroxy-3-methoxyphenyl)-2-propanone (Guaiacyl acetone) & & 0.20 & 0.40 \\
\hline 14 & 61.86 & 3-Hydroxy-1-(4-hydroxy-3-methoxyphenyl)-1-propanone & & 0.73 & 0.38 \\
\hline \multirow[t]{2}{*}{15} & 70.17 & 4-(3-Hydroxy-1-propenyl)-2-methoxy-phenol (Coniferyl alcohol) & & 3.15 & 0.12 \\
\hline & & Sum & & 12.23 & 730 \\
\hline 16 & 47.81 & 2,6-Dimethoxyphenol (Syringol) & \multirow{10}{*}{ S-types } & 1.89 & 1.41 \\
\hline 17 & 53.77 & 3,5-Dimethoxy-4-hydroxytoluene (4-Methyl syringol) & & 3.40 & 3.67 \\
\hline 18 & 58.45 & 4-Ethyl-2,6-dimethoxyphenol (4-Ethyl syringol) & & 0.43 & 1.79 \\
\hline 19 & 60.72 & 3,5-Dimethoxy-4-hydroxystyrene (4-Vinyl syringol) & & 1.92 & 1.61 \\
\hline 20 & 66.03 & 4-Hydroxy-3,5-dimethoxy-benzaldehyde (Syringaldehyde) & & 4.83 & 3.41 \\
\hline 21 & 67.46 & 1-(3,5-Dimethoxy-4-hydroxyphenyl)propyne & & 0.20 & 0.14 \\
\hline 22 & 68.20 & 2,6-Dimethoxy-4-(2-propenyl)-phenol (Methoxyeugenol) & & 3.09 & 2.04 \\
\hline 23 & 69.93 & 1-(4-Hydroxy-3,5-dimethoxyphenyl)-ethanone (Acetosyringone) & & 2.71 & 1.56 \\
\hline 24 & 71.78 & 3,5-Dimethoxy-4-hydroxyphenylacetic acid (Homosyringic acid) & & 0.22 & 0.18 \\
\hline \multirow[t]{4}{*}{25} & 82.13 & 3,5-Dimethoxy-4-hydroxycinnamaldehyde (Sinapyl aldehyde) & & 1.92 & 0.85 \\
\hline & & Sum & & 20.61 & 16.66 \\
\hline & & Total concentration & & 33.96 & 24.39 \\
\hline & & $\mathrm{G} / \mathrm{S}$ ratio & & 0.59 & 0.44 \\
\hline
\end{tabular}

이 결과를 근거로 하여 $\mathrm{G} / \mathrm{S}$ 비를 계산하였다. $\mathrm{DFRC}$ 법에 의한 $\mathrm{G} / \mathrm{S}$ 비는 형질전환체, 정상재 모두 0.4 이 었으나 분석용 열분해 산물의 정량을 통해 산출된 $\mathrm{G} / \mathrm{S}$ 비는 형질전환체, 정상재 각각 $0.44,0.59$ 로 정 상재의 비가 DFRC 법에 의해 산출된 결과보다 더
높았다. 이는 리그닌으로부터 분해된 $\mathrm{G}, \mathrm{S}$ type의 정 량적 분석이 가능한 실험방법들 중 특정하게 더 정확 한 결과를 나타내는 실험방법이 아직 존재하고 있지 않기 때문에 실험 결과를 해석하는데 있어 한계점이 라 볼 수 있다(Aldwin et al., 2002). 하지만 이 결과 
를 통해 리그닌의 주요 결합양식인 $\beta-\mathrm{O}-4$ 결합을 선택적으로 분해하는 것으로 알려진 DFRC 분석결 과로 확인할 수 없었던 정상재와 형질전환체의 $\mathrm{S}$ type과 G type의 비율의 변화를 분석용 열분해를 통해 확인할 수 있었으며, $\mathrm{CCOAOMT}$ 형질 억제에 의한 syringyl 그룹의 감소로 인하여 리그닌 단량체들의 결합양식이 변화될 수 있다고 판단된다. 한편, ${ }^{13} \mathrm{C}$ $\mathrm{NMR}$ 분석을 통해 형질전환체의 특징적인 화합물인 5-hydroxyguaiacyl에 해당하는 3-methoxycatechol 의 함량은 $0.74 \%$ 로 정상재의 $0.45 \%$ 보다 높았으며, 정량된 리그닌의 총량이 정상재 $33.9 \%$, 형질전환체 $24.4 \%$ 인 점을 감안한다면, 형질전환체에서 생성된 3-methoxycatechol의 함량이 상대적으로 더 증가했 음을 추정해 볼 수 있다. 그 이외에도 정상재에 비해 형질전환체의 syringyl group 함량이 $20.6 \%$ 에서 $16.7 \%$, guaiacyl group의 함량이 $12.2 \%$ 에서 $7.3 \%$ 로 감소하였음을 확인할 수 있었고, 특히 coniferyl alcohol의 함량이 $3.2 \%$ 에서 $0.12 \%$ 로 크게 감소하였 다. Coniferyl alcohol의 감소에 관한 정확한 원인을 열분해 생성물을 통해 설명할 수 없지만, $\mathrm{CCoAOMT}$ 활성 억제에 의해 caffeic acid의 ferulic acid로의 전 이가 원활하게 이루어지지 않아 결국 coniferyl alcohol의 함량이 감소하였다고 잠정적으로 추측해 볼 수 있다.

\section{4. 결 론}

본 연구를 통해 리그닌 생합성 경로에서 방향족 고 리의 3 번과 5 번 탄소에 위치한 하이드록실 그룹을 메톡실그룹으로의 전이 반응에 관여하는 효소인 $\mathrm{CCoAOMT}$ 유전자의 발현이 억제되었을 때 $\mathrm{G}, \mathrm{S}$ type 모노머의 함량이 감소됨과 동시에 현사시나무 목부의 리그닌 함량이 감소됨을 확인하였다. 현사시 나무의 정상재와 $\mathrm{CCoAOMT}$ 형질전환체 목부의 화학 조성과 MWL의 결합구조 및 $\mathrm{H}, \mathrm{G}, \mathrm{S}$ type의 모노머 의 함량에 관한 분석을 실시한 결과 $\mathrm{CCoAOMT}$ 유전 자의 발현이 억제되었을 때 현사시나무의 리그닌 함 량이 $21.7 \%$ 에서 $18.3 \%$ 로 감소되었음을 확인할 수 있었고, 분석형 열분해기를 통해 $\mathrm{G}, \mathrm{S}$ type 모노머 함량이 $12.2 \%$ 에서 $7.3 \%, 20.6 \%$ 에서 $16.7 \%$ 로 각각
감소하였다. 위 결과를 바탕으로 $\mathrm{CCOAOMT}$ 활성 억 제는 리그닌 함량을 감소시키기 때문에 목질계 바이 오매스의 활용을 위한 전처리 단계인 탈리그닌화 과 정의 비용을 절감할 수 있을 것이라 기대된다. 하지 만 유전자의 형질억제에 따른 효소의 활성여부가 리 그닌의 생성과 식물 생장에 관한 주요 요소이기 때문 에 분자생물학적 관점에서 추가적인 연구가 필요하 다고 판단된다.

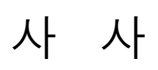

본 연구는 한국연구재단의 신진교수연구지원사업 (KRF-2008-331-F00027)의 지원에 의하여 이루어진 것입니다.

\section{참 고 문 헌}

1. Anterola, A. M. and N. G. Lewis. 2002. Trends in lignin modification: a comprehensive analysis of the effects of genetic manipulations/mutations on lignification and vascular integrity. Phytochemistry 61: 221 294.

2. Baker, S. M. 1996. Rapid methoxyl analysis of lignins using gas chromatography. Holzforschung 50: $573 \sim 574$.

3. Boudet, A. M., S. Kajita, J. Grima-Pettenati, and D. Goffner. 2003. Lignins and lignocellulosics: a better control of synthesis for new and improved uses. Trends Plant Sci. 8: 576 581.

4. Erickson, M., S. Larsson, and G. E. Miksche. 1973. Gaschromatographishe analyse von lignioxydations-produkten. VIII. Zur struktur des lignins der fichte. Acta chemica scandinavica 27: 903 914.

5. Faix, O., D. Meier, and I. Fortmann. 1990. Thermal degradation products of wood. Hoz als RohWerkstoff 48: 351 354.

6. Guo, D., F. Chen, J. Wheeler, J. Winder, S. Selman, M. Peterson, and R. A. Dixon. 2001. Improvement of in-rumen digestibility of alfalfa forage by genetic manipulation of lignin O-methyltransferases. Transgenic Res. 10: 457 464.

7. Lu, F. and J. Ralph. 1997. Derivatization followed 
by reductive cleavage (DFRC method), a new method for lignin analysis: Protocol for analysis of DFRC monomers. J. Agric. Food Chem 45: 2590 2592 .

8. Marita, J. M., J. Ralph, R. D. Hatfielda, D. Guo, F. Chen, and R. A. Dixon. 2003. Structural and compositional modifications in lignin of transgenic alfalfa down-regulated in caffeic acid 3-O-methyltransferase and caffeoyl coenzyme A 3-Omethyltransferase. Phytochemistry 62: 53 65.

9. Marita, J. M., J. Ralph, C. Lapierre, L. Jouanin, and W. Boerjan. 2001. NMR characterization of lignins from transgenic poplars with suppressed caffeic acid O-methyltransferase activity. J. Chem. Soc., Perkin Trans 1: 2939 2945.

10. Pilate, G., E. Guiney, K. Holt, M. Petit-Conil, C. Lapierre, J. C. Leple, B. Pollet, I. Mila, E. A. Webster, H. G. Marstorp, D. W. Hopkins, L. Jouanin, W. Boerjan, W. Schuch, D. Cornu, and C. Halpin. 2002. Field and pulping performances of transgenic trees with altered lignification. Nature Biotechnology 20: 607 612.

11. Ralph, J., C. Lapierrec, J. M. Marita, H. Kinm, F. Lu, R. D. Hatfielda, S. Ralph, and C. Chapple. 2001. Elucidation of new structures in lignins of CADand COMT-deficient plants by NMR. Phytochemistry 57: 993 1003.

12. Ralph, J. and R. D. Hatfield. 1991. Pyrolysis-GC-MS characterization of forage materials. J. Agric. Food Chem 39: 1426 1437.

13. Sluiter, A., B. Hames, R. Ruiz, C. Scarlata, J. Sluiter, D. Templeton, and D. Crocker. 2008. Determination of structural carbohydrates and lignin in biomass. Golden, CO, USA: National Renewable Energy Laboratory.

14. Wise, L. E., M. Murphy, and A. A. D'Addieco. 1946. Chlorite holocellulose, it's fraction bearing on summative wood analysis and on the hemicelluloses. Paper trade journal 122: 35 43. 